\title{
China's Infrastructure Financing and the Role of Infrastructure in Awakening African Economies
}

Michael Mitchell Omoruyi Ehizuelen, Center of Nigerian Studies at the Institute of African Studies, Zhejiang Normal University, China

\begin{abstract}
African economies, through Agenda 2063, recognize that developing infrastructure-transport, electricity, energy, water, and e-connectivity-will be critical for the region to assume a lasting place in the global economic system. As a result, this paper addresses the continent's infrastructure gap and provides an important insight into the rapidly growing presence of China's official infrastructure financing in Africa as well as the distinctive character of its involvement. In addition, the paper provides an empirical evaluation of the role of infrastructure in awakening African economies. The generalized-method-of-moments (GMM) estimator for dynamic models of panel data developed by Arellano and Bond and Arellano and Bover was employed to estimate an infrastructure-increased growth model.
\end{abstract}

\section{KEYWORDS}

Africa, China, Economic Growth, Financing, Infrastructure

\section{INTRODUCTION}

From an economic perspective, an adequate supply of infrastructure services has long been viewed by both academics and policymakers as a key ingredient for economic development. They are necessary to enhance the competitiveness of African firms and facilitate the flow of goods, services, persons and information within and across African economies and regions. As such, one of the critical ingredients in meeting the new continental and global sustainable development goals, namely the African Union (AU)'s Agenda 2063 and the 2030 Agenda for Sustainable Development Goals (SDGs) challenges is infrastructure. Nowadays, almost a fifth of the \$94 trillion in global infrastructure investment required by 2040 risks being unfunded if present spending trends continue (Reuter, 2017). However, the world invests some US\$2.5 trillion dollars a year in infrastructure in order to tackle the problem (MGI, 2016). Yet, this amount continues to fall short of the world's ever-expanding needs, which results in lower economic growth and deprives citizens of essential services. To close the spending gap, annual infrastructure spending needs to rise. The world needs to invest around 3.8 percent of its GDP, or an average of $\$ 3.3$ trillion a year, in economic infrastructure just to support expected rates of growth from 2016 through 2030 (MGI, 2016). Emerging economies account for some 60 percent of that need. But if the current trajectory of underinvestment continues, the world will fall short by roughly 11 percent, or $\$ 350$ billion a year (MGI, 2016).

In Africa, however, underdeveloped infrastructure continues to be a binding constraint on sustainable development. African nations have paid insufficient attention to maintaining and expanding

DOI: $10.4018 /$ JCAD.20210701.oa2

This article published as an Open Access article distributed under the terms of the Creative Commons Attribution License (http://creativecommons.org/licenses/by/4.0/) which permits unrestricted use, distribution, and production in any medium, provided the author of the original work and original publication source are properly credited. 
their infrastructure assets, creating economic inefficiencies and allowing critical systems to erode. According to Agenda 2063, building world-class infrastructure together with trade facilitation should see intra-African trade growing from less than 12 percent currently to about 50 percent by 2045 and the African share of global trade rising from 2 percent to 12 percent. ${ }^{1}$ Attempts to quantify the macroeconomic effects of scaling up infrastructure investment has found significant positive effects. Speaking of macroeconomic effects, the relationship between infrastructure and economic growth is empirically robust in the macroeconomic and microeconomic literature (Sahoo and Dash 2009; Estache, 2006; Calderon and Serven, 2003; World Bank, 1994; Munnell, 1990; Aschauer, 1989). Infrastructure in various forms plays a critical role in promoting home-grown entrepreneurs, foreign investors, economic development, and growth globally. Some kinds of infrastructure are vital because they contribute to economic expansion processes. There are four diverse sets of economic infrastructure - (i) irrigation for the agriculture sector, (ii) the information and communications (ICT), (iii) power generation, (iv) and transport infrastructure (road, rail, ports, and airports). They have a huge multiplier effect (a dollar spent on infrastructure leads to an outcome of greater than two dollars).

By contrast, social infrastructure, like sanitation and water predominantly delivers developmental results. These two sets of social and economic infrastructure interact. For instance, a transport system which is distributed throughout the economy, including rural areas and to regions of relatively low income has vital development influences. In the same way, good sewerage and sanitation improve the welfare of workers and required for several goods in export markets and therefore contributes to economic expansion. Another important characteristic of infrastructure is based on the fact that, infrastructure is the distinction between soft and hard infrastructure. The former is mirrored in physical investments (for instance, water treatment plants, ICT networks, roads, power plants, and irrigation networks), whilst the latter refers to the institutions in which the hard infrastructure is embedded (for instance, sanitation system design and customs clearance procedures). Furthermore, infrastructure can play a vital role in improving the living standards of people (Straub, 2011).

By the same token, one of the key impediments to growth in low and middle-income nations is the shortfall in infrastructure investment, i.e., the failure to keep up with the investments required to support economic expansion and meet social demands for infrastructure. Africa's wealth of natural resources has seldom translated into wealth for its citizens. While the reasons for this are myriad, a dearth of viable infrastructure has been a clear barrier to the long-term development of African economies. Nowhere is a dearth of infrastructure more critical and potentially transformational than in sub-Saharan Africa. In 2009, the World Bank, multilateral institutions, and major donors examined the challenge of addressing the region's glaring infrastructure gaps. ${ }^{2}$ The investigation projected that the region required $\$ 93$ billion per year to fill the infrastructure gap, from the 2006 Africa infrastructure Country Diagnostic (AICD) (quoted in Foster and Briceno-Garmendia 2010).

However, new estimates by the African Development Bank (AfDB) suggest that the continent's infrastructure needs US\$130-US\$170 billion a year, with a financing gap in the range of US\$67.6US $\$ 107.5$ billion (AfDB, 2018). ${ }^{3}$ Reducing this gap needs improvement in efficiency and quality of public investment in infrastructure and mobilization of public and private finance. Why numerous nations in sub-Saharan Africa (SSA) are not capable of financing these investments on their own due to limited domestic sources, the region must rely heavily on overseas investment. A substantial portion of these investments are now coming from non-traditional sources: The private sector and emerging nations, especially China (Foster et al., 2008; UNCTAD, 2008; Moyo, 2009). This could be a game-changer for financing Africa's transformation.

From the policy viewpoint, while the rise of funding for infrastructure is welcome if the resources are not channeled sufficiently, the risk is that the funds will be invested in a way that would not contribute to economic expansion and development, and will thus be wasted partially or completely. According to Mold (2012), the last infrastructure "boom" in the region in the 1960s and 1970s, facilitated by high commodity prices, had negative consequences: A lot of the nation's built "white elephant" projects - large, expensive, highly visible but non-productive investment that did 
not necessarily contribute to the long-term economic expansion of the local economy and ultimately led to an unsustainable level of debt. Based on annual data for 2000-2012 from World Bank's World Development Indicators, the author used the generalized-method-of-moments (GMM) estimator for dynamic models of panel data developed by Arellano and Bond (1991), and Arellano and Bover (1995) to estimate an infrastructure-increased growth model. The overall aim of this paper is to better understand the novel financial flows going into infrastructure in Africa from China as well as assessing the role of infrastructure in awakening African economies. The rest of the paper is structured as follows: Section 2 deals with the state of infrastructure in Africa; section 3 presents infrastructure financing from China; section 4 assesses the role of infrastructure in awakening SSA economies via the analyses of the study empirical results. Section 5 concludes the paper.

\section{THE STATE OF INFRASTRUCTURE IN AFRICA}

The connection between economic infrastructure and growth is extensively documented. In developed nations like the United States, there is an observed impact of infrastructure on total productivity growth (Aschauer 1989). With that said, even though economic returns to infrastructure investment drop as per capita income upsurges (Canning 1999, Auty, 2008), the rate of investment in infrastructure is nevertheless greater in developed nations than in developing nations. In addition to the growing impacts of infrastructure, there is proof that these investments contribute to more equal distributional results. According to Calderón, C. and Servén (2004) study of 100 nations over the period between 1960 and 2000 confirmed both the growth-enhancing and income distributing consequences of augmented infrastructural investment. The positive distributional impact of investment in infrastructure is confirmed in an analysis of headway towards meeting the MDG goals, displaying a positive correlation between infrastructure investment and decreases in infant mortality and improvements in nutrition (Fay et al., 2004). In spite of the obvious connection between growth, development and infrastructure and the consequently high payoffs to investment in infrastructure, a variety of surveys have recognized a significant infrastructure gap in the continent of Africa. This infrastructure gap applies to both economic and social infrastructure and has major implications for economic growth.

Research shows that inadequate infrastructure in Sub-Saharan Africa (SSA), that is electricity, water, roads, and information and communications technology (ICT), lessen national economic growth by two percentage points yearly and cut business productivity by as much as 40 percent (Escribano et al al, 2008; Deloitte, 2013), and that this negative impact was greater the lower the per capita income of the economy. A World Bank report of the condition of infrastructure in the continent of Africa concluded that "for most nations, the negative economic impact of deficient infrastructure is at least as large as that linked with financial market constraints, corruption, crime, and red tape" (Foster et al, 2008). What is more, Africa's infrastructure stock is low, especially in power (see Table 1). Over 640 million Africans have no access to energy, giving an electricity access rate for African nations at just more than 40 percent -the world's lowest (AfDB, 2018). The report added that per capita consumption of energy in SSA (excluding South Africa) is $180 \mathrm{kWh}$, against 13,000 kWh per capita in the United States and 6,500 kWh in Europe. Access to energy is vital not only for attaining health and education results, but also for lessening the cost of doing business and unlocking economic potential creating employment. Insufficient access to modern energy causes hundreds of thousands of deaths each year due to the use of wood-burning stoves for cooking; handicaps the operations of hospitals and emergency services; compromise educational achievement, and drives up the cost of doing business.

With that said, Africa economic growth and development are intrinsically connected to infrastructure development, but it is the push-pull relationship with commodities that have become the driving force for infrastructure development in the continent. Large commodities find, such as oil and gas in East and South-East Africa, as well as the huge demand -especially from Asia -for agricultural and natural resources, including minerals such as iron ore, platinum, coal and copper are 
Table 1. Preliminary figures on investment needs (\$billions)

\begin{tabular}{|c|c|c|c|}
\hline Infrastructure subsector & Target by 2025 & Annual cost & Notes \\
\hline Power & $\begin{array}{l}100 \% \text { urban electrification } \\
95 \% \text { rural electrification }\end{array}$ & $35-50$ & New Deal on Energy target by 2025 \\
\hline Water supply and sanitation & $\begin{array}{l}100 \% \text { access in urban area } \\
100 \% \text { access in rural area }\end{array}$ & $56-66$ & $\begin{array}{l}\text { Water access includes: Piped water, } \\
\text { public tap/standpost, safe wells/ } \\
\text { boreholes. } \\
\text { Sanitation access includes: Improved } \\
\text { latrines, safe pit latrines, septic tank, } \\
\text { and sewer }\end{array}$ \\
\hline $\begin{array}{l}\text { Information and } \\
\text { communication technology }\end{array}$ & $\begin{array}{l}\text { Mobile universal coverage } \\
50 \% \text { of population within } \\
25 \mathrm{~km} \text { of a fiber backbone. } \\
\text { Fiber to home/premises } \\
\text { internet penetration rate } \\
(10 \%)\end{array}$ & $4-7$ & \\
\hline $\begin{array}{l}\text { Road and other transport } \\
\text { sectors (air, rail, and port) }\end{array}$ & $\begin{array}{l}80 \% \text { preservations; } 20 \% \\
\text { development }\end{array}$ & $35-47$ & $\begin{array}{l}\text { Preservation: Maintenance and } \\
\text { rehabilitation } \\
\text { Development: Upgrading and new } \\
\text { construction }\end{array}$ \\
\hline Total & & $130-170$ & Preliminary figures \\
\hline
\end{tabular}

Source: AfDB, 2018

driving the need for infrastructure in turn, investment in infrastructure needed to extract and move these commodities to worldwide markets (rail and port infrastructure) continue to drive Africa's economic growth. The dearth of infrastructure is a serious obstacle to growth and development, and results in a low level of intra-Africa trade and trade with other regions. The continent accounts for 12 percent of the world population but generates only 1 percent of worldwide GDP and only 2 percent of world trade. In spite of this, five of the top ten fastest growing economies in the world in 2019 are in Africa, and four of these nations are in Sub-Saharan Africa (SSA) (Deloitte, 2019). This gives even more reason to speed up the infrastructure transformation on the continent. In addition, as one of the flagship projects of the African Union Agenda 2063, the African Continental Free Trade Area (AfCFTA) aims to create a single market economy to enable the free movement of goods, which may see over one billion people benefits from a combined GDP of nearly US $\$ 3.3$ trillion (Deloitte, 2019).

Therefore, investing in African infrastructure is both a necessity and an opportunity to "leapfrog" AfCFTA and the continent development strategies in all spheres of African economic and social activity. This is because according to the World Bank's doing Business Report 2018, the parameter on trading across borders records the time and cost associated with the logical process of exporting and importing goods, ${ }^{4}$ border compliances for exports in Sub-Saharan Africa take 60-80 percent more time than the regions of East Asia, and Pacific, South Asia and Latin America and the Caribbean. Cost of documentary compliance for exports from Sub-Saharan Africa is also nearly twice the cost in Latin America and the Caribbean region (see Table 2). Also, African producers and consumers are not only disadvantaged by the poor availability and uneven distribution of economic and social infrastructure, but also by its high cost. Typically, costs are two to three times the levels prevailing in other developing regions, with a much greater differential compared to the costs faced by users in high-income economies (Table 3) (Sy, 2017). Additionally, border management and logistics costs need to be substantially lessened for the economies in the region to bolster value chains. Affordability is also a challenge. Infrastructure service costs in Africa are several multiples higher than in other developing regions, whether for power, water, transport, or ICT (AfDB, 2018). According to Dethier 
Table 2. Regional Comparison of Time and Costs for Trading Across Borders

\begin{tabular}{|l|l|l|l|l|l|l|l|l|}
\hline \multirow{2}{*}{ Region } & \multicolumn{3}{|c|}{ Border Compliance } & \multicolumn{3}{c|}{ Documentary } \\
\cline { 2 - 10 } & $\begin{array}{c}\text { Time to } \\
\text { export } \\
\text { (hours) }\end{array}$ & $\begin{array}{c}\text { Cost to } \\
\text { export } \\
\text { (US\$) }\end{array}$ & $\begin{array}{c}\text { Time to } \\
\text { Import } \\
\text { (hours) }\end{array}$ & $\begin{array}{c}\text { Cost to } \\
\text { import } \\
\text { (US\$) }\end{array}$ & $\begin{array}{c}\text { Time to } \\
\text { export } \\
\text { (hours) }\end{array}$ & $\begin{array}{c}\text { Cost to } \\
\text { export } \\
\text { (US\$) }\end{array}$ & $\begin{array}{c}\text { Time to } \\
\text { import } \\
\text { (hours) }\end{array}$ & $\begin{array}{c}\text { Cost of } \\
\text { import } \\
\text { (US\$) }\end{array}$ \\
\hline East Asia \& Pacific & 55.9 & 387.5 & 70.5 & 431.0 & 68.2 & 112.1 & 65.6 & 111.4 \\
\hline Europe \& Central Asia & 28.0 & 191.4 & 25.9 & 185.1 & 27.9 & 113.8 & 27.3 & 94.7 \\
\hline $\begin{array}{l}\text { Latin America \& } \\
\text { Caribbean }\end{array}$ & 62.5 & 526.5 & 64.4 & 684 & 53.3 & 110.4 & 79.9 & 119.5 \\
\hline $\begin{array}{l}\text { Middle East \& North } \\
\text { Africa }\end{array}$ & 62.6 & 464.4 & 112.3 & 540.7 & 74.3 & 243.6 & 94.5 & 266.2 \\
\hline OECD high income & 12.7 & 149.9 & 8.7 & 111.6 & 2.4 & 35.4 & 3.5 & 25.6 \\
\hline South Asia & 59.4 & 369.8 & 113.8 & 638 & 77 & 179.5 & 104.7 & 341.6 \\
\hline Sub-Saharan Africa & 100.1 & 592.1 & 136.4 & 686.8 & 87.8 & 215.1 & 103 & 300.1 \\
\hline
\end{tabular}

Source: EXIM Bank (2018)

(2015) report, having all economies globally reducing supply chain barriers could upsurge worldwide GDP up to six times more than removing all import tariffs.

Besides access, adequacy, affordability, and cost, the quality of infrastructure services is vital for productivity and economic growth. This is particularly evident when compared with other developing regions, electricity in Africa is not only scarce and expensive but also unreliable. Between 2006 and 2016, 79 percent of companies in SSA experienced power outrages - on average 8.6 power outrages a month, with an average duration of 5.7 hours (AfDB, 2018). Almost 60 percent of companies operating in the continent consider infrastructure (power shortages and cost and transport bottlenecks) as the most binding constraint they face in the everyday operation. Even though most African nations have enhanced their electricity generation capacity, their headway in power distribution has been painfully slow, making the generated electricity unusable for productive purposes (World Bank, 2014). Reliable transport infrastructure is vital for landlocked nations, for which it is a precondition to opening production zones. Reliable transport must be in place for firms to import and export products, to fill orders, and to obtain supplies. For instance, 78 percent of Burkina Faso's trade is carried by four main roads and rail corridors connecting the nation to the gateway ports in Benin, Cote d' Ivoire, Ghana, and Togo (World Bank, 2009). Notably, 80 percent of the economic activity in Senegal is concentrated in Dakar (APIX, 2011). And South and East Africa, port congestion and shipment

Table 3.The high cost of Africa's infrastructure for consumers

\begin{tabular}{|l|l|l|}
\hline & \multicolumn{1}{|c|}{ SSA } & \multicolumn{1}{|c|}{ Other developing regions } \\
\hline $\begin{array}{l}\text { Transport } \\
\text { Road freight tariff (\$/ton/km) }\end{array}$ & $0.04-0.14$ & $0.01-0.04$ \\
\hline Power tariffs (\$kWh) & $0.02-0.46$ & $0.05-0.1$ \\
\hline ICT & & 9.9 \\
Mobile (\$basket/month) & $2.6-21.0$ & 2 \\
International (3 min to US) & $0.44-12.5$ & 11 \\
Internet dial up (\$/month) & $6.7-148.0$ & $0.03-0.6$ \\
\hline Water (\$/m3) & $0.86-6.56$ & \\
\hline
\end{tabular}

Source: Derived from Africa Infrastructure Diagnostic 2008, cited in Sy, 2017 
delays undermine the ability to acquire imported production inputs, with resulting production losses and higher production costs (USITC, 2009).

Improvement in infrastructure, therefore, have the potential to open up production zones and facilitate product delivery while lessening their costs. Although roads are the predominant mode of transport, much of Africa's road network is unpaved, isolating people from basic education, health services, transport corridors, trade hubs, and economic opportunities - especially in regions with high rainfall. Road safety is worrisome, with the region recording the highest rate of fatalities from road traffic injuries globally, at 26.6 per 100, 000 people for 2013 (WHO, 2015). Estimates show that road crashes cost about 1 percent to 3 percent of a nation's yearly GDP (US $\$ 100$ billion yearly in developing nations) (AfDB,2013). For instance, Uganda has one of the worst road safety records in SSA, with an average rate of 45 fatalities per 10,000 vehicles. Uganda is estimated to lose approximately 2.7 percent of its GDP via losses of life and property. This is equivalent to the proportion of GDP spent on the road sector (AfDB, 2013). Similar quality constraints are seen in port infrastructure where - in addition to limited capacity in terminal storage, operation, and maintenance - numerous ports dearth the capacity even to handle large vessels. And they are hamstrung by inadequate infrastructure networks in the hinterland, such as railway lines and roads connected to ports, frequently leading to long delays at the ports (AfDB, 2018). In 45 African nations, neither the current stock nor the access nor quality of infrastructure drives economic growth in a context of low basic infrastructure endowment (Kodongo and Ojah, 2016).

This is because inadequate infrastructure has raised the transaction costs of business in most African economies. Nowadays, African nations exhibit the lowest levels of productivity of all lowincome nations and are among the lowest competitive economies globally. Inadequate infrastructure shaves up 2 percent off Africa's average per capita growth rates. (Foster and Briceno-Garmendia 2010). With adequate infrastructure, African companies could attain productivity gains of up to 40 percent (AfDB et al. 2014). Infrastructure that is sufficient and work properly is vital for the continent's economic integration. The continent can start the process of deep integration if their infrastructure networks are designed in such a way as to connect production centers and distribution hubs across Africa, as the networks of developed economies do. Such infrastructure will enable the continent to compete effectively, tap into regional markets, and benefit from globalization via investment and trade. Until then, the productivity loss brought about by poor infrastructure will not go away without commitments by policymakers and leaders to embark on ambitious investments in the sector. It is in this context of investment and weak infrastructural provision in the continent, we try to examine what contributions has China made in the past, and what contribution is the nation making now to close the infrastructure gap in Africa.

\section{CHINA'S INFRASTRUCTURE FOOTPRINT IN AFRICA}

Industrialization, diversification of trade, regional economic integration are all the right ingredients for Africa's sound economic future. Without productive infrastructure in place, the sound economic future might just be a missed opportunity. With that said, during the last great age of globalization (1880-1914), the world was awash in ambitious infrastructure projects, many of which still define the contours of the world we inhabit: The Panama Canal, the Brooklyn Bridge, the Tran-Siberian railroad to name a few. Not all were intended for transnational use, but they spoke of a certain confidence and an unprecedented desire to bind the world together. And just as Africa was always a draw for every dreamer, schemer, and colonizer of the 19th and 20th centuries, so too has it proven in $21 \mathrm{st}$ century. Only this time around it has a new patron. Gone are the explorers and legal impresarios from Lisbon, London, and Liège; in are the engineers from China. Across Africa, novel laws are being implemented and alternative sources of infrastructure financing are being sought so as to kick-start direly needed infrastructure projects. At the center of it all is China, which is offering alternative sources financing to African nations that have not been able to access funding in more traditional 


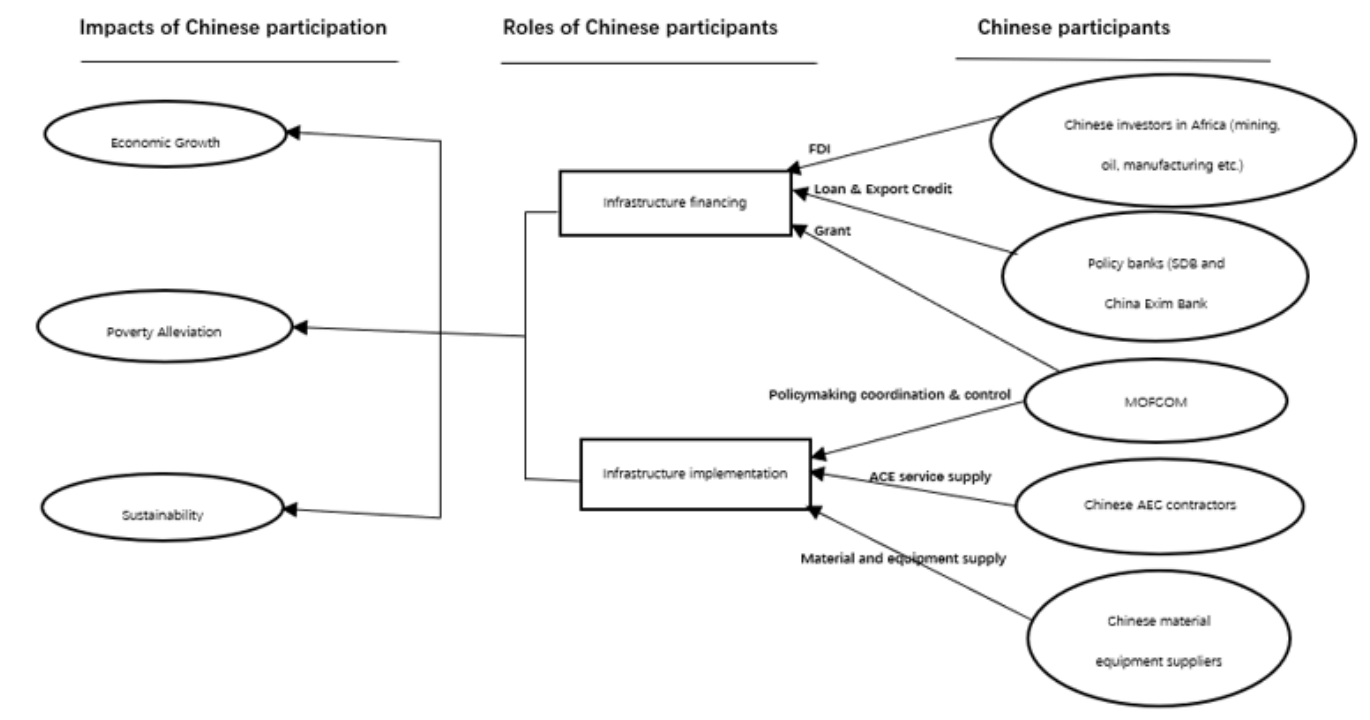

ways. The upsurge in infrastructure development in Africa is partly due to the strong diplomatic ties between Africa and China.

This is reflected in the presence of 49 Chinese diplomatic missions and embassies in Africa and 47 Africa diplomatic missions in China (Sy, 2017). Chen's description of Chinese engagement in large infrastructure projects demonstrates the bundled nature of these activities (Figure 1). According to Ian and Sajal (2018) citing Johns Hopkins SAIS China Africa Research Initiative data, China's identifiable SSA infrastructure debt financing overwhelmingly consisted of policy or commercial bank lending to government authorities (see figure 2), either independently or as part of a consortium of developmental financial institutions. Notably, Sy (2017) asserts that while the operations of some state institutions are confined to the funding of infrastructure (e.g. China EXIM Bank) and some private companies are solely involved in implementation, other parties like MOFCOM and large (predominantly state-owned) companies are involved in both the funding and execution aspects of the infrastructure cycle. With that said, Ian and Sajal (2018) added that Chinese commercial lenders (who follow their Chinese corporates clients) were observed to be significantly less active in extractive industry projects, such as mining, oil and gas. With that said, Chinese state-owned enterprises are diversifying into infrastructure equity investment. As a result, of the 56 SSA projects with a Chinese sponsor from 2014-2018, 66 percent were funded by Chinese state-owned enterprises (SOEs), as opposed to the usual sponsor -the Government of China (Ian and Sajal, 2018). The majority of SOE sponsored projects are still in the planning stage, highlighting their novelty. With that said, in 2017 alone, China financed over $6,200 \mathrm{~km}(3,850$ miles) of railways and more than $5,000 \mathrm{~km}$ of roads in Africa. Among them are the US\$4 billion Addis Ababa -Djibouti Railway, a 750km line connecting landlocked Ethiopia- home to Africa fastest growing economy -to Djibouti on the coast of the Red Sea. ${ }^{5}$

Source: Chen (2010)

Source: Ian and Sajal, 2018 cited from John Hopkins SAIS China Africa Research Institute, Fitch Rating

China's activities have been divided fairly evenly among two main sectors: power generation (especially hydropower), and transport (especially railroads), followed by the ICT sector (mainly equipment supply). Water projects attracted the least amount of activity. ${ }^{6}$ According to Wu and Bai (2017), China's investment in Africa has a clear competitive advantage. The author added that China 
Figure 2. Chinese Loans to African Governments, by Lender (US\$ billion)

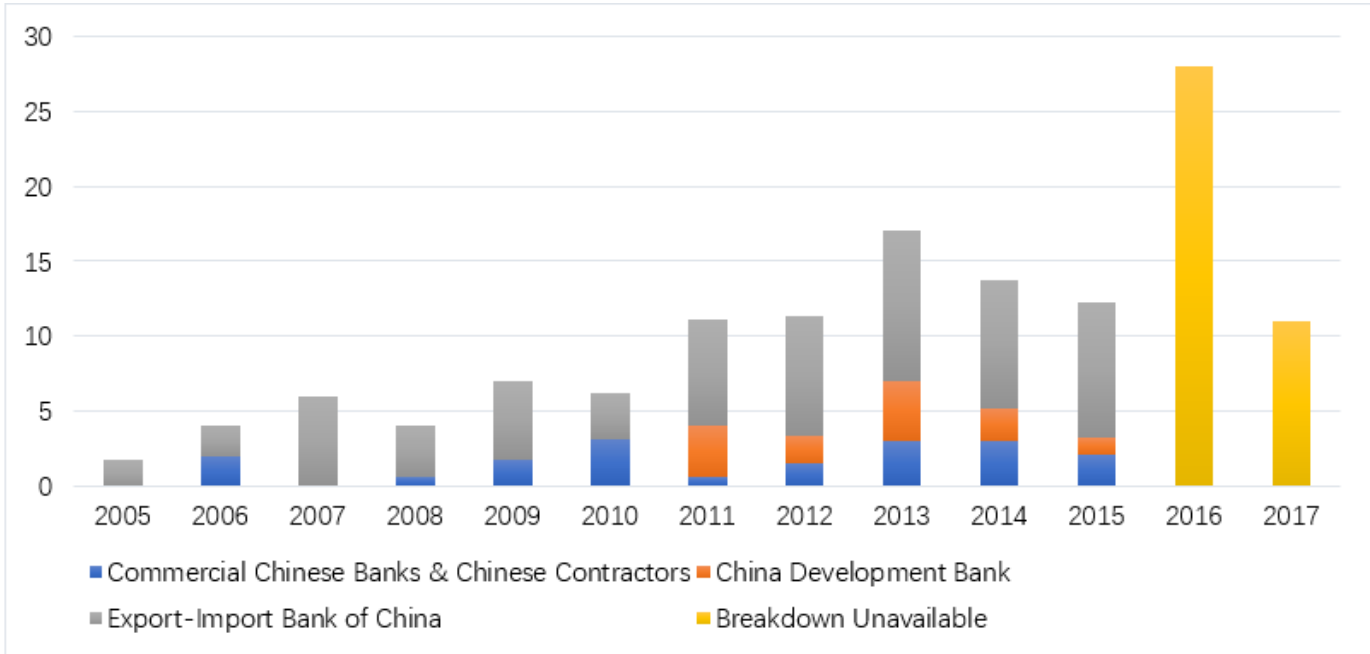

offers lower quotations for investment in infrastructure development, attributable primarily to the mature technology and efficient engineering of Chinese businesses in the field, therefore greatly shortening construction schedules without compromising on quality. With that said, China and Africa can combine the national development needs and demand in fostering economically-beneficial projects and drive Africa's infrastructure construction in a balanced and orderly manner. For African nations, to accelerate domestic socio-economic development, there is an insatiable demand for better infrastructure with most of the funding coming from outside.

China's demand for resources and African demand for infrastructure appears to have created a unique opportunity for mutual gain that has gone unrecognized by China. In 2015, the total infrastructure deficit reached US $\$ 83.4$ billion, of which US $\$ 20.9$ billion came from China. ${ }^{7}$ Notably, in Sub-Saharan Africa (SSA), Chinese lenders accounted for over 40 percent of all infrastructure finance in 2017. In addition, Chinese commercial and policy bank lending for infrastructure projects in SSA totaled US\$3.6 billion in 2014, US\$3.4 billion in 2015 and US\$3 billion in 2016, before spiking nearly 300 percent to US $\$ 8.8$ billion in 2017 , driven by a series of large power projects across the continent (Baker and McKenzie, 2019). ${ }^{8}$ Baker and McKenzie (2019) added that Chinese banks have been active lenders to infrastructure projects in 19 different nations in Africa in the past four years. On top of that, infrastructure projects in Ethiopia have received US $\$ 1.8$ billion since 2014, Kenyan projects US $\$ 4.8$ billion, Mozambique infrastructure deals US $\$ 1.6$ billion and Nigeria projects US\$ billion from Chinese lenders.

South Africa infrastructure projects have received US\$2.2 billion from Chinese lenders since 2014, Zambia has received US\$1.5 billion and Zimbabwe has seen US\$1.3 billion in loans from Chinese policy lenders since 2014 (Baker and McKenzie, 2019). As a result, China's role in African has been defined by the financing of over 3,000 largely critical, infrastructure projects (Schneidman and Wiegert, 2018). China is building more infrastructure in Africa than any other non-OECD nations, making China by far the fastest growing external source of infrastructure financing among the nonOECD financier (Schiere and Rugamba, 2011). There is the tendency that its financing involvement is set to grow significantly in the future most especially under the Chinese Belt and Road Initiative, a multibillion-dollar plan to connect Asia, Europe and Africa.

Notably, official Chinese investments are now expanding beyond China's earlier focus. That is, financing for resource-endowed nations and is reaching sectors in which it has particular technical expertise - like hydropower - and those that are not as amenable to the private sector - such as 
transport (especially road and rail). China is also assisting to make it cheaper for Africa nations to improve their infrastructure by offering lower projects cost. With the region's limited number of railways, it suffers from a US $\$ 900$ billion infrastructure deficit, only making it more worthwhile for the Chinese investment (Bussieres, 2015). Chinese banks are financing these infrastructure projects with Chinese engineering and construction firms performing the brunt of the work.

To maximize China's growing investments in Africa's infrastructure, Africa leaders must steer infrastructure investment towards maintenance as well as new infrastructure development. Chinese financing is likely to make a considerable contribution toward Africa's needs, especially in the sectors where the gap is largest. Most experts have struggled in identifying the scale of the amounts and deciphering the strategy behind the observed trend. To a certain degree, the problem is that the Chinese government does not have a central entity governing its development assistance and investment relations - these dealings are managed across several national agencies, including Ministry of Finance, Ministry of Commerce, individual Chinese embassies within the respective recipient nations, as well as Ministry of Foreign Affairs.

None of these entities releases consistent longitudinal figures on divestitures recipient nations. Another layer of the complication is that in the Chinese situation most of their large-scale investments in the region are linked to its trade and aid and are motivated by Chinese state-owned enterprises (SOEs) (Kaplinsky and Morris, 2010). It is frequently problematic as several of the interventions, particularly those in infrastructure, is a mix of the two: Conversely, much of the Chinese development assistance comes in the form of concessional loans which could be viewed as development assistance. Much of the overseas investment by private firms are secured by bilateral agreements, making the monetary risks on the Chinese firms negligible and thus substantially dissimilar from the traditional overseas investment (Lum et al, 2009; Salidjanova, 2011). This is opposed to the private participation in infrastructure (PPI) funding, which is based on monetary closure for a project, and ODF, which is mainly based on projects once they are officially negotiated and formally approved (like the board of multilateral banks) (Gutman et al, 2015). As a result, there is a wide variation in the estimates of China's infrastructure funding. The question is how much infrastructure supports do the Chinese offer to SSA? In order to answer this question, we will look at some compilation from some scholars, international organization as well as some scholars at the Brookings Institute who decided to compile data from World Bank and its Public-Private Infrastructure Advisory Facility (PPIAF).

Based on the compilation from some scholars at the Brookings Institute, they assert that the World Bank report titled Building Bridges: China's Growing Role as Infrastructure Financier for Sub-Saharan Africa, offered estimates through 2007 (Foster, et al., 2009). They added that the outcome shows substantial growth in China's support, from less than $\$ 1$ billion yearly before 2004 to over $\$ 4$ billion by 2007 . The growth included projects "under reconsideration," "under execution," "completed," and "approved" (Gutman et al, 2015). The dearth of agreement of inclusion or exclusion of "projects under reconsideration" exemplifies the problems deliberated above, as it signified 34 percent of the projects including numerous key rail and power projects in Nigeria worth $\$ 5.5$ billion in 2006 (Gutman et al, 2015).

Unfortunately, the World Bank did not publish an update of this report, so they have to go to other sources to get an outlook of more current trends. They notice that China's financial involvement in SSA has been soaring appreciably from $\$ 313$ million in 2000 to $\$ 4.4$ billion in $2012 .{ }^{9}$ Within this period, the average yearly flow between 2007 through 2012 was about $\$ 5$ billion, well beyond any other single bilateral or multilateral source, with a particular surge in 2010 (Gutman et al, 2015). Furthermore, the Infrastructure Consortium for Africa (ICA) (ICA, 2014) puts Chinese infrastructure investment at approximately $\$ 14.9$ billion for 2011, \$13.4 billion for 2012, and $\$ 13.4$ billion for 2013 - entirely for SSA. If all these estimates are validated, then the Chinese is evidently the largest single source of financing for infrastructure in the region outside of the national budget.

With that said, according to the international law firm Baker and McKensie, between 2009 and 2014, the Chinese signed \$328 billion worth of construction projects (Olander 2016). Through 
Table 4. Number of power projects with Chinese participation in sub-Saharan Africa between 2010 and 2020

\begin{tabular}{|c|c|c|c|c|c|c|}
\hline & \multicolumn{3}{|c|}{ Generation Capacity } & \multicolumn{3}{|c|}{ Transmission and Distribution Capacity } \\
\hline & $\begin{array}{l}\text { Completed } \\
\text { projects }\end{array}$ & $\begin{array}{l}\text { Current } \\
\text { projects }\end{array}$ & $\begin{array}{c}\text { Planned and } \\
\text { financed } \\
\text { projects }\end{array}$ & $\begin{array}{l}\text { Completed } \\
\text { projects }\end{array}$ & $\begin{array}{l}\text { Current } \\
\text { projects }\end{array}$ & $\begin{array}{c}\text { Planned and } \\
\text { financed projects }\end{array}$ \\
\hline East Africa & 14 & 9 & 5 & 10 & 10 & 1 \\
\hline West Africa & 17 & 4 & 2 & 6 & 2 & 2 \\
\hline Central Africa & 8 & 5 & 2 & 5 & 1 & 2 \\
\hline Southern Africa & 15 & 7 & 8 & 4 & 5 & 1 \\
\hline Total & 54 & 25 & 17 & 25 & 18 & 6 \\
\hline & & 96 & & & 49 & \\
\hline
\end{tabular}

Source: Wu and Bai (2017) "Boosting the Power Sector in sub-Saharan Africa: China's Involvement." July 2016.

Chinese loans, aid packages, and other forms of business operations that are encouraged in Africa, infrastructure is one of the main methods that China uses to develop Africa's economy. With the intensification of China's overseas investment strategy in recent years, the overall scale of China's direct investment in Africa has risen considerably. In terms of answering the call for electrification in Africa, between 2010 and 2015, over half of the 150 power plants and transmission and distribution capacity projects were already completed (IEA, 2016). The remaining ones are either already under construction or planned and financially secured (Table 4).

Announced projects which have not yet reached financial closure are not counted. China's investment encompasses railways, highways, ports, oil and gas fields and power plants, whereas investment from the United States and European nations mostly focuses on energy and power. As many as 322 large-scale projects for infrastructural development began in Africa before June 2013. Around 12 percent of these projects were undertaken by Chinese firms, while 37 percent were undertaken by European and United States firms. ${ }^{10}$ China's approach to investment in infrastructural development in Africa differs from that of the West. While the latter emphasizes on the model of "democracy first," China believes in driving the economic expansion of the receiving nation through infrastructural development. As a result, the West often questions the motive for China's investment and construction support in Africa from its own point of view.

In terms of Chinese contract, the value of contracts newly undertaken by Chinese companies in Africa reached US\$75 billion in 2014 (see figure 3) with a turnover of US\$53 billion, which is 40 times more than the figure in $2000 .{ }^{11}$ Chinese contracts in some sense are more efficient than Western solutions because it brings quick results. With that said, in 2015, Africa Union (AU) and China signed the "most substantive project that AU has ever sign with a partner - a memorandum of understanding to jointly develop infrastructure to link Africa's capital through air transport, road, and rail routes and industrialization projects as part of the Agenda 2063. ${ }^{12}$ This represents another step forward for the African Union's Agenda 2063 to have world-class infrastructure throughout Africa. Furthermore, China made pledges towards the region's infrastructure and development projects worth $\$ 55$ billion at the December 2015 Johannesburg Summit (FOCAC) as well. Out of the $\$ 55$ billion, $\$ 35$ billion will be channel towards the China-Africa Development Fund - private equity and venture capital initiatives by the China Development Bank - and an additional \$5 billion is to be set aside for loans for the development of the region's small and medium enterprises. ${ }^{13}$

In addition, China has been given priority to AU's Programme for infrastructure Development in Africa (PIDA). The PIDA has roughly 51 different programmes and this is translated into 400 different physical projects (Demissie, 2017). Through PIDA programme, China has been able to contribute not only to local infrastructure through buildings and industrial zones, but also to the physical 


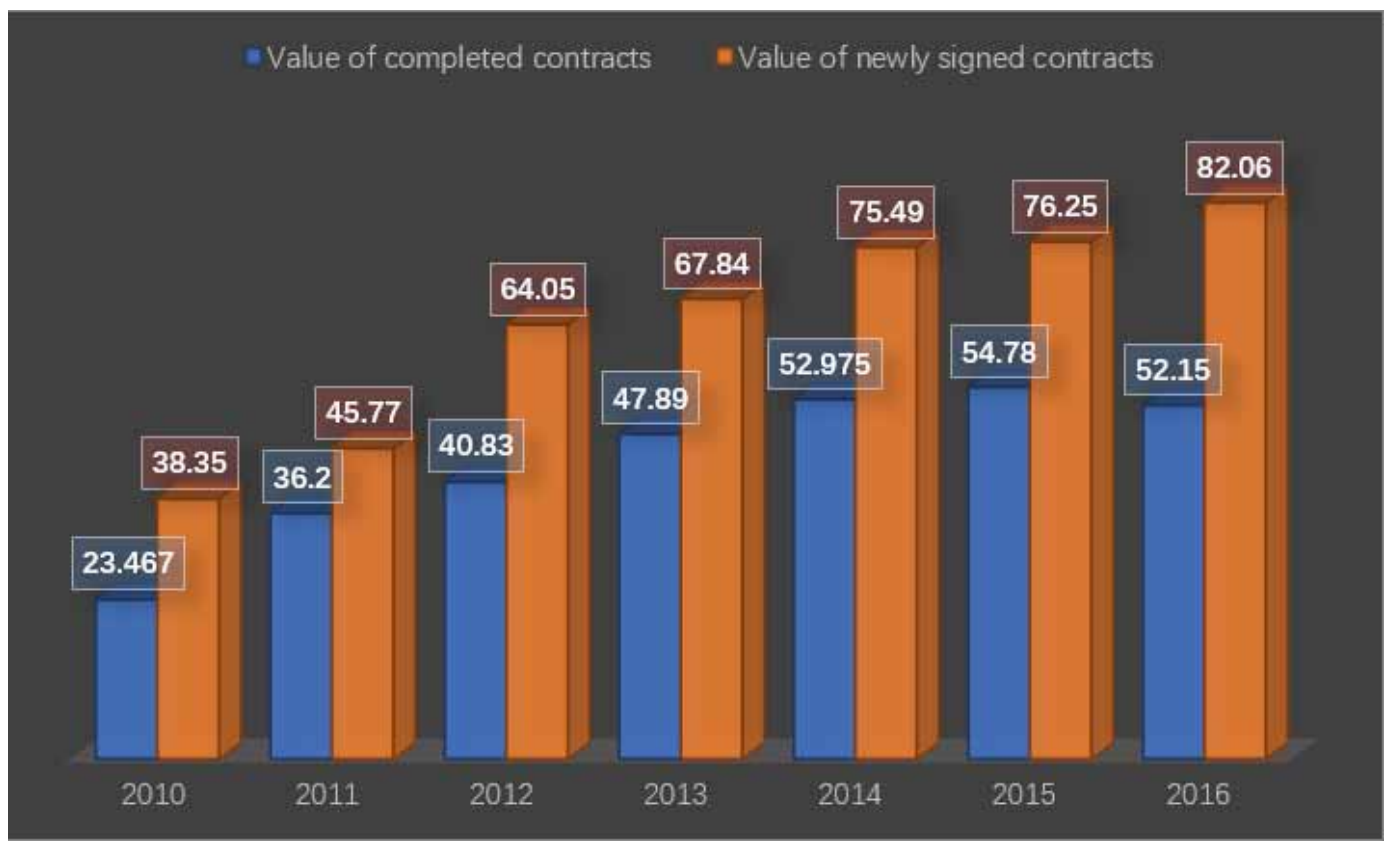

integration of African states through regional projects in the form of roads, railways, waterways, energy infrastructure, and anything the continent needs to function.

Source: China-Africa Trade and Economic Report, 2017

China has also displayed continued resilience in infrastructure financing with both resource-rich and non-resource-rich nation in the region. Additionally, while the Chinese investment in resource-rich nations increased between 2005 and 2012, its investment in non-resource-rich SSA nations augmented by a factor of seven between 2005 and 2012 (Figure 4); also, non-oil nations like Ghana and Ethiopia emerged as the largest recipients of Chinese infrastructure replacing oil-rich Sudan (Figure 5). All these illustrations are an obvious indication suggesting a shift in emphasis, and that there are wider strategic goals behind China's infrastructure financing in the region. China is especially targeting the transport sector, particularly railways and road (Figure 6 and 7). The reason for this is because these are sub-sectors in which the Chinese firms have particular experience and successfully compete for contracts under multilateral financing. They are also sub-sectors that have received less interest from the private investment in the region. Although China is supporting Africa close the continent infrastructure gap, however, these projects do not come cheap. In order to fund these projects, African nations borrowed almost \$10 billion from China EXIM Bank for railways projects from 2004-2014 (Morlin-Yorn, 2017). Although these nations have so far been responsible for the repayment of loans, it is still questionable if these infrastructure projects can be maintained in the future.

Source: Gutman et al, 2015

Source: Gutman et al, 2015

Source: Gutman et al, 2015

Note: * Data was not available for investment prior to 2000. Note: W.S.S represents Water Supply \& Sanitation

Source: Gutman et al, 2015 
Figure 4. Chinese Infrastructure Investment Commitments to Resource-Rich versus Non-Resource-Rich Sub-Saharan African Nations, 2005-2012 (\$Million)

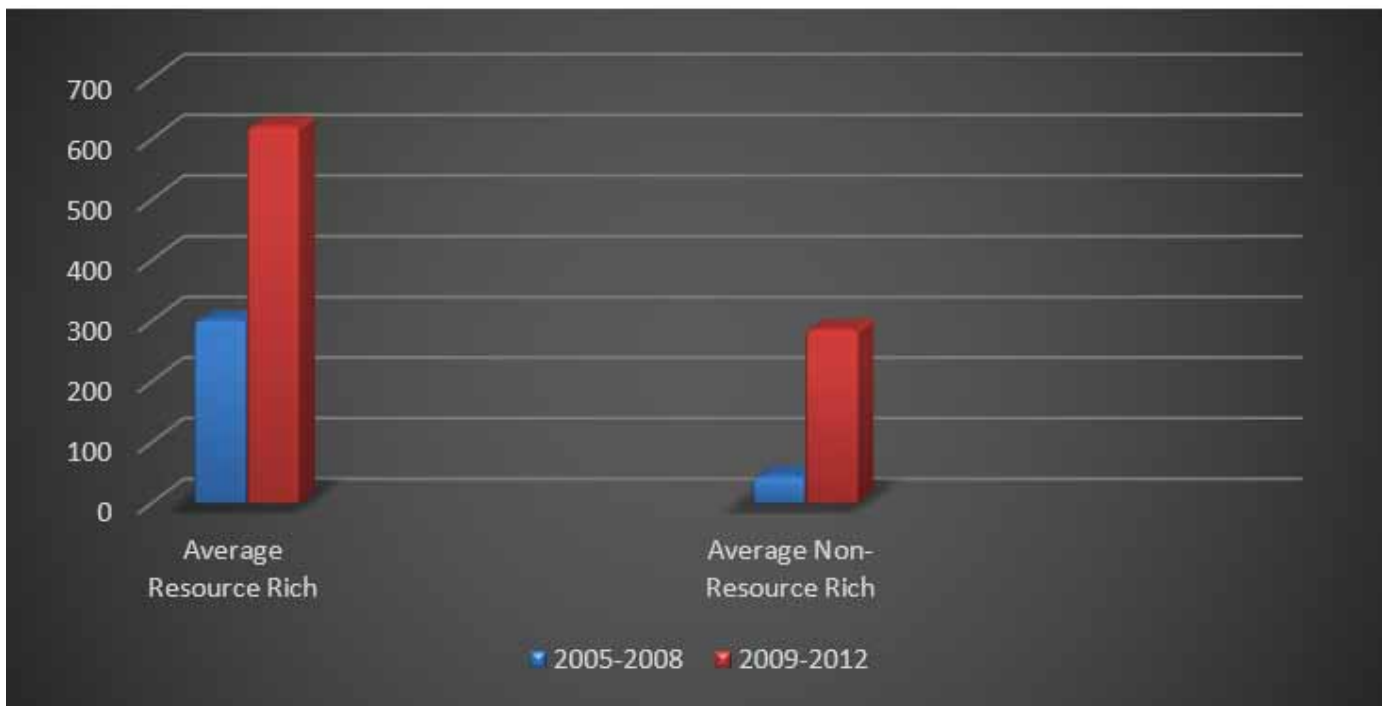

Figure 5. Chinese Infrastructure Investment Commitments in Sub-Saharan Africa, Top Recipient Countries, 2009-2012, in \$US Million (Current)

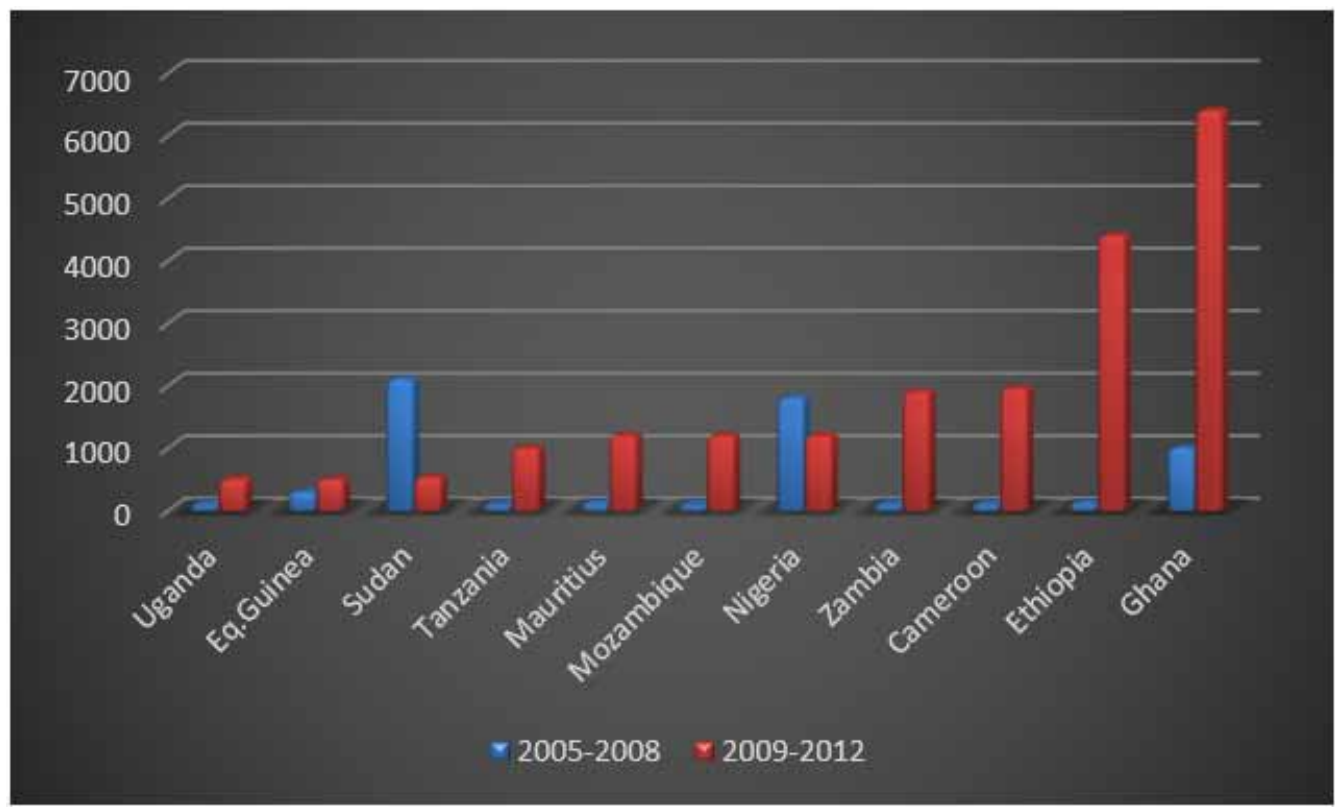


Figure 6. Chinese Infrastructure Investment Commitments in Sub-Saharan Africa, by Sector, 2000-2012, * in US\$ Millions (Current)

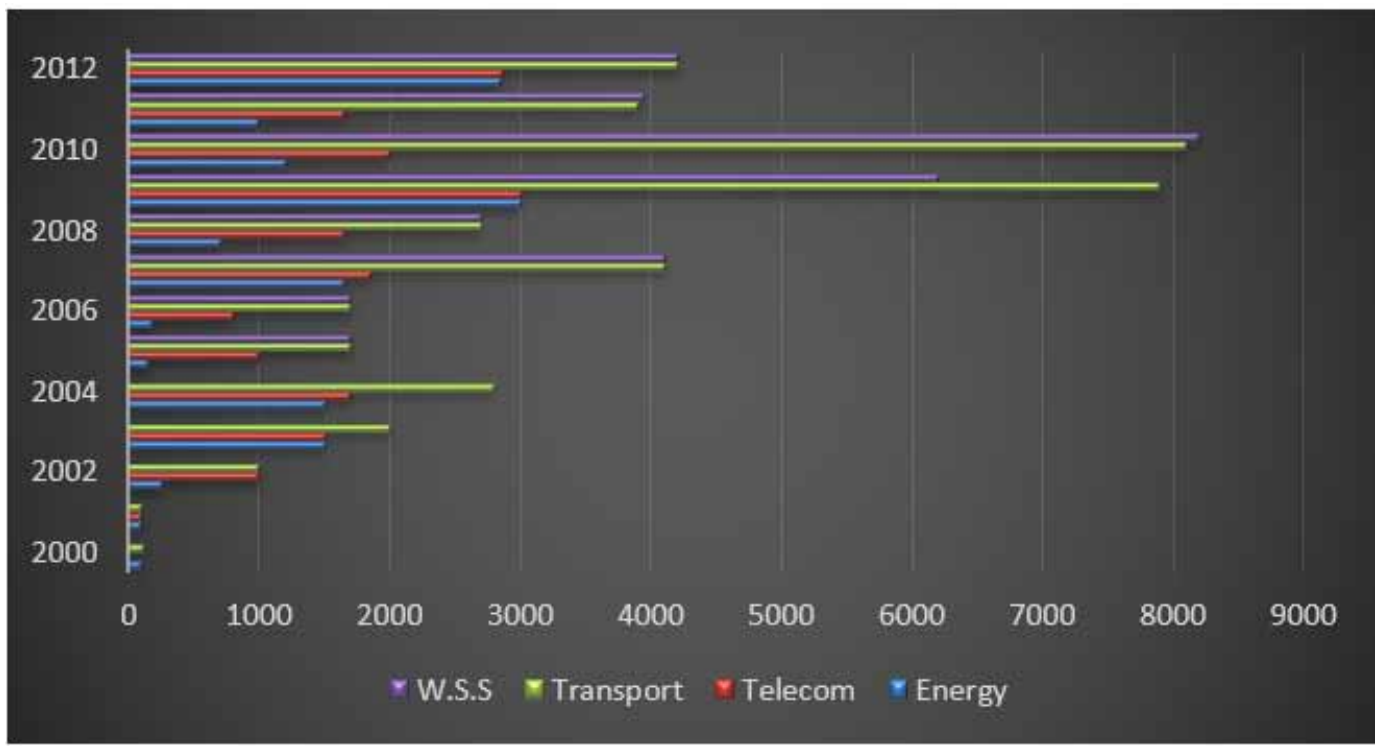

Figure 7. Chinese Infrastructure Investment Commitments in Sub-Saharan Africa, by Sector, 2005-2012, Proportions

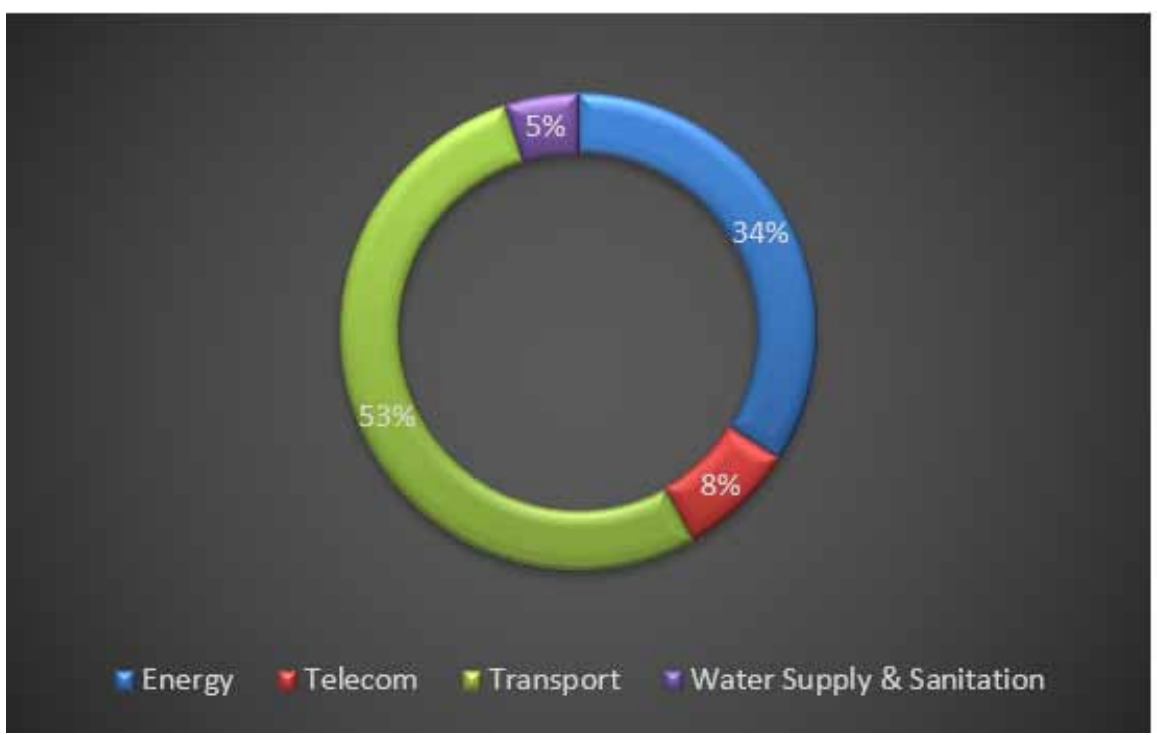

\section{EMPIRICALLY ASSESSING THE ROLE OF INFRASTRUCTURE IN AWAKENING AFRICAN ECONOMIES}

\subsection{Data and Model Specification}

By drawing examples from different projects, the first part attempted to examine the state of Africa infrastructure gap as well as outline some of the most significant infrastructure projects that have 
emerged in Africa simply because of China's interest in investing in the sector. This part provides an empirical evaluation of the role of infrastructure in awakening African economies. As stated earlier, economic growth in Africa is lower than expected; for that reason, the author of the paper argues that if advancing infrastructure development will be the solution of reviving Africa economic growth, then the infrastructure quality will be more important than infrastructure stocks. Emphasis should be placed not on offering infrastructure bulk but on ensuring that the public infrastructure can increase the rate of return on private capital. With that said, the paper employs principal component analysis to construct a representative infrastructure stock index from three variables such as highway, communication infrastructure, and electricity. According to Calderón and Servén (2010), these variables indicate the core infrastructure for developing nations: communication infrastructure (number of telephone lines, mobile subscribers per 1,000 persons), electricity (energy consumption, in Megawatt per 1,000 persons), and highways (kilometers of paved roads, the percentage of paved roads, in kilometer per square kilometer of land area).

Some scholars such as Grubesic (2009), Straub et al. (2008), and Yeaple and Golub (2007) analyze the physical characteristics of infrastructure. In their studies, they assess the performance of three different sectors - communication infrastructure, electricity and highways: main telephone lines or phone number, electricity production capacity, and the length of railway lines or the length of paved roads. In line with their analysis, the author employs the technique suggested by Calderón and Servén (2004). A number of variables like highways network length are not accessible in the long or consistent time series, their accessibility for cross-sections is adequate to offer sufficient data for the index. The study employs all the pooled sample of forty African economies to run the principal component investigation, with the electricity variable expressed in logarithmic form. ${ }^{14}$ The other principal component offers the best weights for the study index construction ${ }^{15}$. From the resulting index, a linear combination of the three underlying metrics is derived as:

$$
\text { Infras }_{q t}=0.358\left(\text { CoMInfras }_{q t}\right)+0.756\left(\text { Elect }_{q t}\right)+0.545\left(\text { Highways }_{q t}\right)
$$

From the above equation, Infras ${ }_{q t}$ represents the index of infrastructure quality, CoMInfras ${ }_{q t}$ Elect $_{q t}$ and Highways ${ }_{q t}$ represents the metrics for Communication infrastructure, electricity, and highways quality respectively. In the same way, the infrastructure stock index is derived from the following variables: electricity (percentage of distribution and transmission losses in the production of electricity), highways (the share of paved roads in total roads), and communication infrastructure (number of secure internet subscribers per 100 persons). The study employs the linear transformation to construct the infrastructure stock index $\left(\right.$ Infras $\left._{s t}\right)$ :

$\operatorname{Infras}_{\mathrm{st}}=0.958\left(\right.$ Elect $\left._{\mathrm{st}}\right)+0.134\left(\right.$ Highways $\left._{\mathrm{st}}\right)+0.897\left(\right.$ CoMInfras $\left._{\mathrm{st}}\right)$

From the above equation, Infras ${ }_{s t}$ represents the index of infrastructure stocks, CoMInfras ${ }_{s t}$ Elect ${ }_{s t}$,

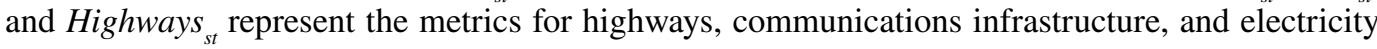
stocks respectively. Most notably, the indexes compare very well with the underlying infrastructure variables, as shown in the pairwise correlations in table 5 below.

Note: Drawing from a large pool of data set of infrastructure stocks covering 40 African economies from 2000-2012, the author evaluates the impact on per capita growth of faster accumulation of infrastructure stocks and of enhancement in the quality of infrastructure service for 40 African economies in three key infrastructure sectors: communication infrastructure, highways, and electricity. The infrastructure quality index is developed as Infras $\mathrm{Qt}_{\mathrm{t}}=0.358\left(\right.$ CoMInfras $\left._{\mathrm{qt}}\right)+0.756\left(\right.$ Elect $\left._{\mathrm{qt}}\right)+$ 0.545 (Highways $_{\mathrm{qt}}$ ), while the infrastructure stock index is developed as Infras $_{\mathrm{st}}=0.897$ (CoMInfras $_{\mathrm{st}}$ ) $+0.958\left(\right.$ Elect $\left._{\mathrm{st}}\right)+0.134\left(\right.$ Highways $\left._{\mathrm{st}}\right)$. The variable "energy consumption of the economy, in 
Table 5. The Links between Infrastructure indices and infrastructure variables.

\begin{tabular}{|l|l|l|}
\hline & $\begin{array}{c}\text { Infrastructure } \\
\text { stock }\end{array}$ & Infrastructure quality \\
\hline Number of secure internet subscribers per 100 persons & & 0.9294 \\
\hline Highway (share of paved roads in total roads) & & 0.6816 \\
\hline Energy consumption of the economy, in Megawatt per 1,000 persons & 0.5516 & \\
\hline Number of telephone lines, mobile subscribers per 1,000 persons & 0.1182 & \\
\hline The road network length, in kilometer, per square kilometer of land area & 0.9512 & 0.6376 \\
\hline $\begin{array}{l}\text { Percentage of transmission and distribution losses in the production of } \\
\text { electricity }\end{array}$ & & \\
\hline
\end{tabular}

\section{Table 6. Data Specification}

\begin{tabular}{|c|c|c|c|c|c|c|c|c|c|c|}
\hline & $\begin{array}{l}\text { Infrastructure } \\
\text { quality }\end{array}$ & $\begin{array}{l}\text { Infrastructure } \\
\text { stock }\end{array}$ & $\begin{array}{c}\text { Human } \\
\text { Dev. Index }\end{array}$ & Inflation & Governance & $\begin{array}{c}\text { Term } \\
\text { of } \\
\text { trade }\end{array}$ & $\begin{array}{c}\text { Private } \\
\text { sector } \\
\text { GDP }\end{array}$ & $\begin{array}{c}\text { Trade } \\
\text { openness }\end{array}$ & $\begin{array}{c}\text { Govt. } \\
\text { expenditure }\end{array}$ & $\begin{array}{c}\text { GDP } \\
\text { per } \\
\text { capita }\end{array}$ \\
\hline \multicolumn{11}{|c|}{ Pairwise correlations } \\
\hline $\begin{array}{l}\text { Infrastructure } \\
\text { quality index }\end{array}$ & 0.423 & 0.163 & 0.335 & 0.194 & -0.096 & 0.119 & -0.058 & 0.504 & 0.209 & 1.000 \\
\hline $\begin{array}{l}\text { Infrastructure } \\
\text { stock index }\end{array}$ & 0.194 & 0.143 & 0.090 & 0.173 & 0.103 & 0.134 & 0.017 & 0.146 & 1.000 & \\
\hline $\begin{array}{l}\text { Human Dev. } \\
\text { Index }\end{array}$ & 0.856 & 0.578 & 0.521 & 0.627 & 0.015 & 0.482 & -0.077 & 1.000 & & \\
\hline Inflation & -0.024 & -0.065 & -0.055 & -0.196 & -0.026 & -0.089 & 1.000 & & & \\
\hline $\begin{array}{l}\text { Governance } \\
\text { (regulatory } \\
\text { quality) }\end{array}$ & 0.421 & 0.095 & 0.064 & 0.261 & -0.031 & 1.000 & & & & \\
\hline Terms of trade & 0.119 & -0.198 & 0.079 & -0.199 & 1.000 & & & & & \\
\hline $\begin{array}{l}\text { Private sector } \\
\text { GDP }\end{array}$ & 0.385 & 0.884 & 0.276 & 1.000 & & & & & & \\
\hline $\begin{array}{l}\text { Trade } \\
\text { openness }\end{array}$ & 0.586 & 0.293 & 1.000 & & & & & & & \\
\hline $\begin{array}{l}\text { Government } \\
\text { expenditure }\end{array}$ & 0.419 & 1.000 & & & & & & & & \\
\hline $\begin{array}{l}\text { GDP per } \\
\text { capita }\end{array}$ & 1.000 & & & & & & & & & \\
\hline Mean & 22.836 & 20.837 & 0.556 & 4.253 & -0.749 & 2.097 & 4.292 & 5.230 & 0.433 & 6.610 \\
\hline Median & 14.968 & 22.156 & 0.544 & 2.493 & -0.690 & 2.000 & 3.249 & 5.204 & 0.358 & 6.276 \\
\hline Std. Dev. & 39.341 & 27.347 & 0.214 & 13.554 & 0.721 & 0.460 & 0.733 & 0.571 & 0.360 & 1.209 \\
\hline Minimum & 0.000 & 0.000 & 0.363 & -9.925 & -2.361 & 0.313 & 0.582 & 3.054 & 0.027 & 4.912 \\
\hline Maximum & 562.99 & 196.37 & 0.884 & 273.0 & 0.989 & 3.553 & 6.022 & 6.382 & 2.516 & 9.649 \\
\hline $\begin{array}{l}\text { Missing } \\
\text { Observations }\end{array}$ & 0 & 0 & 5 & 0 & 40 & 0 & 15 & 0 & 15 & 0 \\
\hline
\end{tabular}

Megawatt per 1,000 persons" is in logarithmic form. Index weights are derived from the second and first principal components, respectively, for the stock and quality indexes.

Note: In the above equation, the lower case "qt" signifies quality while "st" signifies stock

The data specification for all dataset is displayed in table 6. The data comes from pooled statistics of 40 African economies from 2000-2012, gotten from United Nations Development Program 
(UNDP) for Human Development Index (HDI) as well as from World Development Indicators (WDI). Furthermore, GDP growth which is the independent variable, is developed as the log of the ratio of the GDP per capita in period $t$ to GDP per capita in period $t$ - 1 . The study missing variables are skipped in the computations. In addition to the above variables, the study added human capital as a control variable. Human capital is vital for the reason that it allows a nation's pool of labor resources to obtain solid skills such as the capability to operate machines and soft skills such as effective communication and collaboration which can potentially improve the productivity of capital. To categorize the nations and to reflect the development status, to date, there are many conceptual frameworks.

The Human Development Index (HDI) whose components are life expectancy, gross national income per capita and anticipated years of schooling that is published by the United Nations Development Programme is widely accepted and practiced by many people such as academicians, politicians, and donor organizations. The HDI was introduced as an alternative to conventional measures of economic development such as income per capita and the rate of economic growth. The methodology and indicators for calculating the HDI were revised in the 2010 and 2014 Human Development Reports (HDR), even the current version of the index formulation published in 2016 needs research to better understand and to gap-fill the knowledge base that can enhance the index formulation.

Formerly, the Human Development Index (HDI) measures a nation's success in the following human development achievements for its citizens: a long and healthy life (using health data), access to knowledge (using education data where school enrolments rates were employed in place of national income and the two years schooling variables) and a decent standard of living (using income per capita i.e. $\log$ GDP per capita at purchasing power parity (PPP)). Statistics for the Human Development Index (HDI) are not obtainable for numerous years. So, in order to better understand and to gap-fill the observations, the author first estimate the 2010 index as the sums mean of 2009 and 2011 HDI indices, and then run an ordinary least squares regression of HDI indices for 2007-2012 against interception and period. The study found out that the regression yielded a time coefficient that is positive and statistically highly significant in 39 of 40 African economies used in the study. Based on the assumption of the linear relationship between time and HDI, the author then extends the application to Human Development Index (HDI) for 2002-2005.

The study realizes that the maximum values of the two infrastructure indexes are fairly high. An investigation displays that the fairly high values can be partly ascribed to South Africa, who has developed a sophisticated infrastructure including a one-of-a-kind micro-fiber-optic network for the entire nation. The findings display why South Africa standout in the study as a better nation when compared to other nations in the region in terms of infrastructure development. Indeed, Kumo (2012), using South African data, confirms strong bidirectional causality between infrastructure investment and economic growth. Nations with quicker rising output may spend additional fund on infrastructure while infrastructure provision may also positively mediate the correlation between aggregate input and output, and hence foster output growth (Kodongo and Ojah, 2016). Also, the author notices that the term of trade data display that, for the median nations in Africa, the total revenues from export are used to fund imports.

This is because across the continent of Africa, numerous African economies are dependent on the production and export of primary commodities as a result of their incapability to add value to their export structure from unprocessed raw products to processed - finalized products. The greater part of imports is likely to be consumables rather than raw materials for production. As a result, African nations find it difficult to improve their export competitiveness and advance the achievement of their development agendas. For that reason, at this preliminary phase, terms of trade appear not to be favorable to growth. To solve this problem, the African Development Bank has prioritized industrialization in its High 5 agenda. This could create a huge opportunity for African nations to add value to their raw materials. It is this regard that the Bank's Annual Meetings for 2018 has the theme "Accelerating Africa's Industrialization." 


\section{METHODOLOGY}

To assess the impact of infrastructure on growth, the study employs a yearly large macroeconomic data set encompassing 40 African economies and spanning the years 2000-2012, in order to test the subsequently augmented growth model on a panel of 40 African economies. This will help provide an avenue to understand the infrastructure provision effect in awakening African economies. ${ }^{16}$ To analyze the nexus between infrastructure and economic growth, the equation (3) is estimated.

$Y_{i, t}=\alpha y_{i, t-1}+\beta^{\prime} K_{i t}+\beta^{\prime} X_{i t}+\eta_{t}+\mu_{i}+\varepsilon_{i t}$

where: $Y_{i, t}$ denotes the growth rate of GDP per capita; $K$ denotes all other determinants factors supposedly affecting the growth rate, such as terms of trade, human capital, inflation, output per capita, financial depth, government expenditure, trade openness, and governance; $X$ denotes infrastructure-related measures, comprising of variables and indices of quality of infrastructure and stock of infrastructure. The terms $\eta_{t}$ and $\mu_{i}$ respectively denote an unobserved common factor affecting all economies as well as a country effect capturing unobserved country characteristics; $\alpha$ is the convergence coefficient, and $\varepsilon_{i t}$ is the serial correlation test of the error term. As a result of the potential endogeneity in the statistics, the estimation method will be carried out via the generalized method of moments (GMM) for dynamic panel data models developed by Arellano and Bond (1991), and Arellano and Bover (1995). It should be noted that the GMM treats unobserved country-specific factors via differencing. Also, the estimation process comprises of time-specific dummies to control for homogenous factors that may affect the economic expansion of the examined nations.

\section{FINDINGS}

To account for the potential endogeneity of infrastructure (as well as that of other regressors), the author of the paper uses a variety of generalized-method-of-moments (GMM) estimators based on both internal and external instruments and report results using both disaggregated and synthetic measures of infrastructure quantity and quality. As such, parameters of the GMM estimator for the growth equation increased by infrastructure stock and quality as displayed in table 6 . Table 6 transmits the standard parameter estimates (commonly known as standard beta) of infrastructure metrics, along with the parameter estimates for control variables which are usually agreed in the literature as standard growth interpreters.

The regression comprises of time dummies and an interception to control for factors that are general to the entire economies. The findings display that indicators such as human capital, inflation (as a percentage change in the consumer price index), trade openness, terms of trade, and governance (as a proxied by regulatory quality) have a positive and significant influence in awakening African economies. As for inflation, the coefficients have a positive sign which implies that an increase in the price of consumer products and service, if driven by demand, could bring about an increase in economic productivity, which is considered beneficial and in turn contributes positively in awakening African economies. Drawing from a large pool of dataset, the study finds that both infrastructure indicators have a positive coefficient, as anticipated. A variety of specification tests suggests that these results do capture the causal impact of the exogenous component of infrastructure quantity and quality in awakening African economies. Therefore, this result suggests that infrastructure quality can be a significant competitive advantage to Africa's industries and can be highly effective to combat poverty in the continent.

As for the stock of infrastructure, the index has an insignificant coefficient in the study estimates as would have been expected also. This finding is not in line with the growing number of literature arguments that claim that the public capital stock has significant, positive effects on private sector output, productivity and capital formation (Chitiga et al., 2016), Akekere et al. (2017), and Munnell 
Table 7. Empirical findings for the baseline regression of forty African economies

\begin{tabular}{|c|c|c|c|}
\hline & First Equation & Second Equation & Third Equation \\
\hline Infrastruture quality & & $\begin{array}{l}0.003 * * \\
(0.00)\end{array}$ & $\begin{array}{l}0.003 * * \\
(0.00)\end{array}$ \\
\hline Infrastructure stock & $\begin{array}{l}0.003 \\
(0.00)\end{array}$ & & $\begin{array}{l}0.002 \\
(0.00)\end{array}$ \\
\hline Human Development Index & $\begin{array}{l}0.922 * * * \\
(0.37)\end{array}$ & $\begin{array}{l}0.812^{* *} \\
(0.38)\end{array}$ & $\begin{array}{l}0.951 * * \\
(0.41)\end{array}$ \\
\hline Inflation & $\begin{array}{l}0.002 * * \\
(0.00)\end{array}$ & $\begin{array}{l}0.002 \\
(0.00)\end{array}$ & $\begin{array}{l}0.002^{*} \\
(0.00)\end{array}$ \\
\hline Governance (regulatory quality) & $\begin{array}{l}0.054 * * * \\
(0.02)\end{array}$ & $\begin{array}{l}0.048 * * * \\
(0.02)\end{array}$ & $\begin{array}{l}0.052 * * * \\
(0.02)\end{array}$ \\
\hline Terms of trade & $\begin{array}{l}0.035^{* *} \\
(0.02)\end{array}$ & $\begin{array}{l}0.040^{* *} \\
(0.02)\end{array}$ & $\begin{array}{l}0.038^{* *} \\
(0.02)\end{array}$ \\
\hline Monetary depth & $\begin{array}{l}-0.069 * * * \\
(0.02)\end{array}$ & $\begin{array}{l}-0.056^{* *} \\
(0.03)\end{array}$ & $\begin{array}{l}-0.064 \\
(0.03)\end{array}$ \\
\hline Trade openness & $\begin{array}{l}0.049 * * \\
(0.02)\end{array}$ & $\begin{array}{l}0.046^{*} \\
(0.02)\end{array}$ & $\begin{array}{l}0.051^{*} \\
(0.02)\end{array}$ \\
\hline Government spending & $\begin{array}{l}0.042 \\
(0.04)\end{array}$ & $\begin{array}{l}0.040 \\
(0.05)\end{array}$ & $\begin{array}{l}0.038 \\
(0.05)\end{array}$ \\
\hline Lagged GDP per capita & $\begin{array}{l}0.896^{* * * *} \\
(0.05)\end{array}$ & $\begin{array}{l}0.914 * * * \\
(0.12)\end{array}$ & $\begin{array}{l}0.898 * * * \\
(0.06)\end{array}$ \\
\hline Constant & $\begin{array}{l}0.478 \text { *** } \\
(0.10)\end{array}$ & $\begin{array}{l}0.404 * * * \\
(0.12)\end{array}$ & $\begin{array}{l}0.452 * * * \\
(0.12)\end{array}$ \\
\hline Observations & 397 & 397 & 397 \\
\hline Specification tests (p-values) AR (2) & 0.17 & 0.18 & 0.16 \\
\hline Sargan-Hansen test & 0.88 & 0.97 & 0.89 \\
\hline
\end{tabular}

(1992). Apart from the above findings, another strand of recent literature has examined the effect of infrastructure in awakening African economies. The underlying idea is that, under suitable conditions, infrastructure stocks (proxied employing a synthetic index almost as the same as this study) can have a positive impact in awakening African economies (Calderon and Serven, 2010). Based on the above results as well as the present state of African infrastructure deficit, one would anticipate that a marginal change in the stock of infrastructure should bring about a positive impact in awakening African economies. However, that is not the case. The result shows that a change in the stock of infrastructure does not bring about any positive impact in awakening African economies

Note: The study estimates a system GMM employing yearly data of 40 African economies for the period 2000-2012. The dependent variable is growth in GDP (log of the ratio of GDP per capita in year $t$ and GDP per capita in year $t-t)$. The regression comprises of an interception and time dummies; strong standard errors are in parentheses. ${ }^{*}, * *, * * *$ denote statistical significance at 10 percent, 5 percent and 1 percent, respectively.

Table 7 reports the test finding for 40 African economies. The finding shows that infrastructure plays a vital role in propelling higher public and private investment, increase attractive job opportunities, encourage the efficient use of natural resources, hence, increase the productivity of the public and private sectors as a whole. As for the infrastructure quality coefficients, they are all positive and statistically significant in the test findings. These findings, thus, propose that as a strong contributor to economic development and poverty reduction, emphasis should be placed not on 
offering infrastructure bulk but ensuring that public infrastructure is of the standard that can upsurge the rate of return on public and private capital and, hence, increase output. For example, this may mean designing a rail network for passenger and general traffic in addition to mineral shipments for resource-rich African nations. Also, pavement management should be taken into consideration because the existence of a long highway network might not be useful in attracting private capital if a large part of the network is effectively unusable due to the highways' poor conditions as well as inadequate maintenance.

Similarly, the provision of a robust electric power supply is vital for encouraging public and private investment. The direct effect is raising the productivity of land, labor, and other physical capital. For example, a steady supply of electricity reduces disruptions and time wasted at the workplace. It complements the contributions of education, health, marketing, and finance. But in the case where electric power supply is not reliable, private businesspersons will be forced to have alternative and expensive stand-by thermal generators, which lessens the return on their invested capital (Malikane, 2014). With that said, it should be noted that, as a result of constant electric power, fast-growing economies have had investment rates of 30 percent of GDP (over 40 percent in some cases), well above those of most African resources-rich nations (Commission on Growth and Development, 2008). The immediate effect of new infrastructure can be substantial, either by increasing output or stimulating new investment in machinery and equipment. When electricity supply disruptions are eliminated or available hours increased, as seen in Bangladesh or the Philippines, farmers and firms respond with a greater supply. Therefore, the role of African governments in providing a stable environment for investment, includes the role the government of different African nations play in providing infrastructure, which will help drive connectivity and economic prosperity. In this study, thus, the quality of infrastructure matters in awakening African economies even in other developing economies that are relatively less endowed with infrastructure stocks.

\section{CONCLUSION}

Notably, this paper is in two different parts. The first part set out to trace the capacity issues for infrastructure development and the financial response to the infrastructure gap in Africa. It started with a document analysis, in which the state of infrastructure and the state of financing were collated from several disparate reports and surveys. It is worth noting that Africa's infrastructure gap is holding back the continent's development and costing almost two percentage point of GDP per year. The study shows that there has been an unprecedented upsurge in financing for Africa infrastructure from China. China sees infrastructure as a perennial challenge facing African economies in attaining economic growth and higher living standard. For the past four decades, infrastructure was one of the ingredients that contributed to China's high growth rate. The scale of China's involvement in Africa is significant and large. But, has this been good for the development of the continent's infrastructure sector? The analysis of this paper says it has.

Indeed, China's infrastructure investment has assisted the continent to deliver extraordinary headway in awakening African economies. Although there are those who would argue that the relationship between Africa and China is mostly a toxic one, by drawing upon different instances of infrastructure projects. However, it can be demonstrated that there are some significant results being made in this sector were backward and forward linkages are created and offer novel opportunities for African nations to develop. China stands out among the new financiers in terms of the funds it has committed to Africa and for its aggressive and ambitious cooperation with the continent. While the scale of the investment response grows, however, the question now is whether it will culminate in an appreciable filling of the gap in terms of overall economic, social, and sustainability goals across the several African nations and sectors.

The second part of this paper examined the role of infrastructure in awakening African economies by employing principal component analysis on three main variables representing highways, 
communication infrastructure, and electricity to developed indices of infrastructure quality and infrastructure stock. Employing those indices and a set of control variables, the study estimated an augmented growth model by employing the System GMM technique. The study findings display that infrastructure quality clarifies economic expansion, while infrastructure stock does not. The interpretation of the findings imply that good infrastructure quality upsurges output and productivity, especially in manufacturing and service delivery, hence, in raising that rate of return on private capital. The study recommends that African leaders should not only put emphasis on the provision of infrastructure bulk but on the provision of infrastructure to the standard that can incentivize manufactures by lessening the cost of capital.

Above all, African nations could find ways of enhancing collaboration and diversify funding options for infrastructure projects via novel funding institutions like the New Development Bank (NDB), Asia Infrastructure Investment Bank (AIIB) and the joint fund with African Development Bank (AfDB) and the People's Bank of China (PBOC) -Africa Growing Together Fund (AGTF). These institutions offer opportunities for African nations to integrate their development initiatives with those of China while offering the institutional mechanisms for better strategic involvement with the Chinese. This will make African nations have less reliance on a single partner and thus less risk of economic downturns negatively affecting the long-term infrastructure projects stated in Aspiration 2 of the continent's Agenda 2063. A development agenda for African nations should, thus, focus on the challenges and opportunities presented in various infrastructure areas.

Another vital issue for African infrastructure development is to ensure adequate maintenance. Notably, African leaders, with help from traditional donors or China, have invested large resources in infrastructure projects without always providing the finances needed for maintenance. For instance, the Chinese-financed flagship Tanzania-Zambia railway project was an amazing accomplishment, with over 1800km of tracks laid through mountainous terrain and 320 bridges built ( $\mathrm{Gu}$ and Schiere, 2011). But today, the Chinese-built Tanzania-Zambia railway has suffered from underinvestment, monetary difficulties and mismanagement for the past 30 years, with the railroad chronically underutilized because of the dearth of a functioning locomotive. Overall, the amount of useable track has declined across Africa between 2005 and 2011, dropping from 58,000 to 50,000 kilometers, underscoring the pressing need for rehabilitation and maintenance in the sector. Poor maintenance has led to the track's deterioration and caused a loss of competitiveness and rolling-stock productivity (Foster and Briceno-Garmendia 2010). Recently, Tanzania and Zambia governments have agreed to take up the responsibility of financing infrastructure maintenance, locomotives and wagons (Atsushi et al., 2017).

With that said, proper using of the available capacity, therefore, requires substantial capital investment in rehabilitation and upgrading; some nations, like Kenya and Ethiopia, have initiated the upgrading process. Additionally, numerous African nations have concessions their railway networks to realize the benefits of a more efficient private sector management. African leaders should, therefore, ensure that adequate resources are provided in government budgets for infrastructure funding projects and maintenance. African government should also focus on the soft side of infrastructure development, by addressing policy and regulatory matters and training to develop monetary packages. In addition to Chinese finding, African government should establish effective infrastructure systems, including autonomous institutions and self-sustaining funding mechanisms. Part of a fuel tax can be directed to road maintenance fund, and a tax on power consumption can be allocated for transmission and distribution maintenance. More generally, proceeds from infrastructure taxes can be directed to funding novel infrastructure, including schools and hospitals. 


\section{REFERENCES}

Leipziger, Woden, \& Yepes. (2004). Achieving child-health-related millennium development goals: The role of infrastructure. World Development, 33(38), 1267-1284.

AfDB. (2013). The Africa infrastructure development index (AIDI), AfDB chief economist complex. Abidjan, Cote d'Ivoire. African Development Bank (AfDB). Retrieved 5 May, 2019 from https://www.afdb.org/file admin/ uploads/afdb/Documents/Publications/Economic_Brief_-_The_Africa_Infrastructure_Development_Index.pdf

AfDB. (2018). African economic outlook 2018. Retrieved 2 July, 2019 from www.afdb.org/en/ Knowledge/ publications/african-economicoutlook/

African Development Bank (AfDB), Organization for Economic Co-operation and Development (OECD) Development Centre, and United Nations Development Programme (UNDP). (2014). Africa Competitiveness Report 2014. Geneva: World Economic Forum.

Akekere, J., Oniore, J.O., Ogbhenebrume, A. D., \& Ekainsai, Z. S. (2017). Industrial sector growth and public infrastructure capital in Nigeria. Journal of Economics, Management and Trade, 19(4), 1-12.

APIX. (2011). Invest in Senegal. Retrieved 19 May, 2019 from http://www.invesinsenegal. com/apix_anglais.html

Arellano, M., \& Bond, S. (1991). Some tests of specification for panel data: Mote Carlo evidence and an application to employment equations. The Review of Economic Studies, 58(2), 277-297. doi:10.2307/2297968

Arellano, M., \& Bover, O. (1995). Another look at the instrumental variable estimation of error-component models. Journal of Econometrics, 68(1), 29-51. doi:10.1016/0304-4076(94)01642-D

Aschauer, D. A. (1989). Is public expenditure productive? Journal of Monetary Economics, 23(2), 177-200. doi:10.1016/0304-3932(89)90047-0

Atsushi, L., Richard, M. H., \& Yonas, E. L. (2017). Model choice between rail and road transportation: evidence from Tanzania. Policy research working paper, WPS8174. World Bank. Retrieved 21 June, 2019 from documents. worldbank.org/curated/en/7337 81504010382743/pdf/WPS8174.pdf

Auty, R. (2008). Natural resources and development. In A. K. Dutt \& J. Ros (Eds.), International Handbook of Development Economics (Vol. 1). Edward Elgar.

Badawi, A. (2003). Private capital formation and public investment in Sudan: Testing the substitutability and complementarity hypotheses in a growth framework. Journal of International Development, 15(6), 783-799. doi:10.1002/jid.1031

Baker and McKenzie. (2019). Funding Africa's infrastructure gap. Retrieved 3 June, 2019 from https://www. bakermckenzie.com/en/newsroom/2019/05/funding-africa's-infrastructure-

Bogetic, Z., \& Fedderke, J. W. (2005). Infrastructure and growth in South Africa: benchmarking, productivity, and investment need. Paper presented at the economic society of South Africa (ESSA) Conference, Durban, South Africa.

Bussieres, P. (2015). Africa and China's construction sector. Retrieved 11 December, 2017 from http:// Thediplomat.com/2015/12/Africa-and-china-construction-market/

Calderón, C., \& Servén, L. (2003). The output cost of Latin America's infrastructure gap. In The Limits of Stabilization: Infrastructure, Public Deficits, and Growth in Latin America. Stanford University Press.

Calderón, C., \& Servén, L. (2004). The effects of infrastructure development on growth and income distribution. Policy research working paper 3400 , World Bank.

Calderón, C., \& Servén, L. (2010). Infrastructure and economic development in Sub-Saharan Africa. Journal of African Economies, 19(AERC Supplement 1), 113-187.

Canning, D. (1999). Infrastructure's contribution to aggregate output. The World Bank, policy research working paper series, 2246. 
Chen, V. (2010). Chinese participation in infrastructure development in Africa: Roles and impact. A publication prepared for the international poverty reduction centre in China and OECD and supported by the European Commission through the EU-China policy.

China-Africa trade and economic relationship annual report. (2017). Chinese Academy of International Trade and Economic Cooperation.

Chitiga, M., Mabugu, R., \& Maisonnave, H. (2016). Analyzing job creation effects of scaling up infrastructure spending in South Africa. Journal of Development South Africa., 33(2), 186-202.

Commission on Growth and Development. (2008). The growth report: Strategies for sustained growth and inclusive development. The International Bank for Reconstruction and Development/ The World Bank.

Deloitte. (2013). Addressing Africa's infrastructure challenges. Retrieved 21 June 2019 from https:// www2.deloitte. com/content/dam/Deloitte/global/Documents/Energy-and-Resources/dttl-er-africasinfrastructure-08082013.pdf

Deloitte. (2019). Africa in 2019 outlook, summary report. Retrieved 12 July, 2019 from https://www2.deloitte. com/content/dam/Deloitte/za/Documents/africa/za_africa_in_2019_outlook_summary_report_022019.pdf

Demissie, A. (2017). China's Belt and Road initiative and Its long-term impact on African countries. A paper presented at the Schiller Institute Conference, Fulfilling the Dream of Mankind. Retrieved November 22, 2018 from http://www.Larouchepub.com/eiw/public/2017/eirv44n49-20171208/29-35_4449.pdf

Dethier, J. J. (2015). Infrastructure in Africa. In The Oxford Handbook of Africa and Economics, Vol. 2: Policies and Practices. Oxford University Press.

Escribano, A. J. G., \& Pena, J. (2008). Impact of infrastructure constraints on firm productivity in Africa. Africa infrastructure diagnostic study, working paper 9, Washington, DC: World Bank.

Estache, A. (2006). Infrastructure: A survey of recent and upcoming issues. The World Bank.

EXIM Bank. (2018). Connecting Africa: Role of transport infrastructure. Export-Import Bank of India, Working Paper No.72.

Foster, Butterfield, \& Chen. (2008). The changing landscape of infrastructure finance in Africa: Non-traditional sources take on a growing role. The World Bank Public-Private Infrastructure Advisory Facility (PPIAF).

Foster and Briceño-Garmendia. (2010). Africa infrastructure: A time for transformation. Africa Development Forum Series. The World Bank. Retrieved 19 January, 2018 from http://documents.worldbank.org/curated/ en/2009/01/11487313/africasinfrastructure-timetransformation

Grubesic, T. H. (2009). The management and measurement of infrastructure: Performance, efficiency and innovation. Growth and Change, (1), 184-187.

Gu, J., \& Schiere, R. (2011). Post-crisis prospects for China-Africa relations. African Development Bank. Working Paper, No 124.

Ian, D., \& Sajal, K. (2018). The infrastructure footrace: Why China fits into Africa's plans for Development. Fitch. Retrieved 4 July, 2019 from https://medium.com/fitch-blog/the-infrastructure-footrace-why-china-fitsinto-africas-plans-for-development-9d4d8cf35cc7

IEA. (2016). Boosting the power sector in Sub-Saharan Africa: China's involvement. OECD/IEA.

Infrastructure Consortium for Africa (ICA). (2014). Infrastructure financing trends in Africa: ICA Report 2013. Tunis, Tunisia: ICA Secretariat, African Development Bank. Retrieved 11 June, 2018 from http://www.icafrica. org/fileadmin/documents/Annual_Reports/ICA-2013-INFRA-FIN-TRENDSAFRICA-2013-FINAL-WEB.pdf

Jeffrey, G., Sy, A., \& Chattopadhyay, S. (2015). Financing African infrastructure: Can the world deliver? Brookings Institute of Global Economy and Development. Washington: Brookings Institution.

Kaplinsky, R., \& Morris, M. (2010). Chinese FDI in sub-Saharan Africa: Engaging with large Dragons. European Journal of Development Research, 24(1).

Kodongo, O., \& Ojah, K. (2016). Does infrastructure really explain economic growth in Sub-Saharan Africa? Working Paper 653, Economic Research Southern Africa, Cape Town, South Africa. 
Kumo, L. W. (2012). Infrastructure investment and economic growth in South Africa: A granger causality analysis. African Development Bank Group. Working Paper Series. No 160.

Lum, T., Fischer, H., Gomez-Granger, J., \& Leland, A. (2009). China's foreign aid activities in Africa, Latin America, and Southeast Asia. Congressional Research Service.

Maliane, C. (2014). The theory of the firm in the African context. In C. Monga \& J. Y. Lin (Eds.), The Oxford handbook of Africa and economics: Context and concepts. Oxford University Press.

Mckinsey Global Institute (MGI). (2016). Bridging global infrastructure gaps. In collaboration with Mckinsey's capital projects and infrastructure practice. Retrieved $25 \mathrm{June}, 2018$ from https://www.un.org/pga/71/wp-content/ uploads/sites/40/2017/06/Bridging-GlobalInfrastructure-Gaps-Full-report-June-2016.pdf

Mold, A. (2012). Will it all end in tears? Infrastructure spending and African development in historical perspective. Journal of International Development, 24(2), 237-254.

Morlin-Yron, S. (2017). China funds railways to link across East Africa. Retrieved 12 January, 2018 from https:// www.cnn.com/2016/11/21/Africa/Chinese-funded-railways-in-africa

Moyo, D. (2009). Dead aid: Why aid is not working and how there is a better way for Africa. Farrar, Straus, and Giroux.

Munnell, A. H. (1990). Why has productivity growth declined? Productivity and public investment. New England Economic Review, 3-22.

Munnell, A. H. (1992). Policy watch: Infrastructure investment and economic growth. The Journal of Economic Perspectives, 6(4), 189-198.

Olander, E. (2016). Chinese-Built infrastructure in Africa may not be as bad as some think. Retrieved from: https://www.huffingtonpost.com/entry/china-infrastructure-africa_us_57b3 2e3ae4b0863b0284d2b3

Relikka, R., \& Svensson, J. (1999). How inadequate provision of public infrastructure and services affect private investment. Policy research working paper series No. 2262. Washington, DC: The World Bank.

Reuter. (2017). World needs $\$ 94$ trillion to spent on Infrastructure by 2040: report. Retrieved 22 December, 2018 from https://www.reuters.com/article/us-global-infrastructure-report/World-needs-94-trillion-spent-oninfrastructure-by-2040-report-idUSKBN1AA1A3

Salidjanova, N. (2011). Going out: An overview of China's outward foreign direct investment. US- China Economic \& Security Review Commission (USCC) staff research report. Retrieved from: https://www.uscc. gov/researchpapers/2011/GoingOut.pdf

Schiere, R., \& Rugamba, A. (2011). Chinese infrastructure investments and African integration. African Development Bank.

Schneidman, W., \& Wiegert, J. (2018). Competing in Africa: China, the European Union, and the United States. Brookings. Retrieved 4 October 2018 from https://www.brookings.edu/blog/africa-in-focus/2018/04/16/ competing-in-africa-china-the-european-union-and-the-united-states/

Sohoo, P., \& Dash, R. K. (2009). Infrastructure development and economic growth in India. Journal of the Asia Pacific Economy, 14(4), 351-365.

Straub, S. (2011). Infrastructure and development: A critical appraisal of the macro-level literature. The Journal of Development Studies, 47(5), 683-708.

Straub, S., Vellutini, C., \& Warlters, M. (2008). Infrastructure and economic growth in East Asia. Policy research working paper series 4589. The World Bank.

Sy Amadou, N. R. (2017). Leveraging African pension funds for financing infrastructure development. African Growth Initiative at Brookings.

United Nations Conference on Trade and Development (UNCTAD). (2008). World investment report: Transnational corporations, and the infrastructure challenge. Geneva: UNCTAD. 
USITC (United States International Trade Commission). (2009). Recent trends in U.S. Services Trade: 2009 annual report. Washington, DC: USITC. Retrieved 7 April, 2019 from http:// www. usitc.gov/publication/332/ pub4084.pdf

WHO. (World Health Organization). (2015). Global status report on road safety 2015. Geneva.

World Bank. (1994). World development report 1994: Infrastructure for development. Oxford University Press.

World Bank. (2009). Africa infrastructure country diagnostic 2009. In Africa's infrastructure: A time for transformation. World Bank.

World Bank. (2014). Expanding the possible in Sub-Saharan Africa: How tertiary institutions can increase growth and competitiveness. Washington, DC: Author.

Wu, Y., \& Bai, X. (2017). China's infrastructure development strategy in Africa: Mutual gain? International Center for Trade and Sustainable Development (ICTSD). ChinalBridges Africa, 6(2). Retrieved April 17, 2018 from https://www.ictsd.org/bridges- news/bridges-africa/news/china\%E2\%80\%99s-infrastructure-developmentstrategy-in-africa-mutual-gain

Yeaple, S.R., Golub S.S. (2007), International productivity differences, infrastructure, and comparative advantage. Review of International Economics, 15(2), 223-242. 


\section{ENDNOTES}

African Union (2014). http://agenda2063.au.int/en/sites/default/files/agenda2063_popular_ version_05092014_EN.pdf This study, Foster and Briceno-Garmendia (Eds) 2009, Africa's Infrastructure: A Time for Transformation was a part of the Africa Infrastructure Country Diagnostic (AICD) project by the World Bank and cosponsored by ICA partners; also referred to in this paper as the 2009 World Bank Report. by all donors to resorb the infrastructure deficit

Doing Business measures the time and cost (excluding tariffs) associated with three sets of procedures -documentary compliance, boarder compliance and domestic transport -within the overall process of exporting or importing a shipment of goods.

5 What to know about China's ties with Africa, from aid to infrastructure. South China Morning Post. 22 July, 2018. Retrieved 2 July, 2019 from https://www.scmp.com/news/china/diplomacy-defence/article/2156279/ what-know-about-chinas-ties-africa-aid-infrastructure. China's Infrastructure Footprint in Africa. Institute of Developing Economies Japan External Trade Organization. Retrieved from www.ide.go.jp/English/Data/Africa_file/Manualreport/cia_10.html The Infrastructure Consortium for Africa. Infrastructure Financing Trends in Africa 2015. November 2016. Chinese funding of Africa infrastructure projects trebles. Infrastructurenews. August 6, 2018. Retrieved 5 July, 2019 from infrastructurenews.co.za/2018/08/06/Chinese-funding-of-african-infrastructure-projectstrebles/

The increase 2009-2010 was as a result to Ghana transport commitments in 2010 ( $\$ 5.9$ billion) and Ethiopia hydropower in 2009 ( $\$ 2.55$ billion). Current Situation and Prospects of China's Infrastructure Investment in Africa." Oriental Morning Post, 16 December 2014.

Relations between New Infrastructure Construction Policies in Africa and China." Xinhua Expatriate Labor Service Center, 8 February 2017.

News24, AU, China agree big infrastructure deal', 27 January 2015, https://www.news24.com/Africa/ News/Africa-Union-China-agree-big-infrastructure-deal-20150127, accessed 30 June 2016. ibid.

The nations examined are Angola, Benin, Botswana, Burkina Faso, Burundi, Cameroon, Central African Republic, Chad, Comoros, Congo (Democratic Republic), Congo (Republic.), Côte d'Ivoire, Eritrea, Ethiopia, Gabon, Gambia, Ghana, Guinea, Kenya, Lesotho, Liberia, Madagascar, Malawi, Mali, Mauritius, Mozambique, Namibia, Niger, Nigeria, Rwanda, Senegal, Seychelles, Sierra Leone, South Africa, Swaziland, Tanzania, Togo, Uganda, Zambia, and Zimbabwe. The best principal component is described as the one that offers the set of weights that yields an index with the highest correlation with each index component.

16 Serious attempts at incorporating the private sector in infrastructure financing started with market reforms in the mid-1990s. This examination seeks to capture the relationships of interest post-reform. Similarly, there is data paucity prior to 2000 for several small economies in the region. Other related surveys have examined specific nations in the region such as South Africa (Bogetic and Fedderke 2005), Uganda (Reinikka and Svensson, 1999), and Sudan (Badawi, 2003). 